Universidade de São Paulo

Faculdade de Saúde Pública
VOLUME 34 NÚMERO 4 AGOSTO 2000 p. 321-22

Joumal of Public Health

\title{
Fatos ou pura ficção em ciência
}

Facts or pure science fiction 


\section{Fatos ou pura ficção em ciência Facts or pure science fiction}

A propósito do poder dos meios de informação, Marcelo Gleiser abre o prefácio de seu proveitoso livro, "Retalhos Cósmicos", escrevendo que "hoje em dia, nada mais comum do que vermos um beduíno, em seu camelo, com sua calça Levi’s e óculos Giorgio Armani, entoando uma canção de Elton John. Na testa do camelo, em árabe, vemos escrito: Lady Di, nós te amamos". Este comentário, de saborosa ironia, com ou sem exageros, dá-nos conta do poder dos meios de informação, exercido com enorme eficácia, mas nem sempre com a devida perfeição, que se estende por todos os campos da atividade humana.

No campo da ciência é sabido que a pressão do processo social, muito bem aproveitada pelos meios de informação, na aceitação ou negação de uma teoria científica acaba levando a uma perspectiva relativista: nas fases iniciais, durante a "moda", o componente social acaba sendo passageiro, para, ao final, prevalecer o componente não passageiro, do quanto a teoria explica determinado fenômeno.

Pode-se reconhecer que os conhecimentos científicos e seus métodos podem ser desconfortáveis, mas tal desconforto é sempre melhor do que a ignorância. Muito embora a ciência não nos ensine a viver, é ela que nos ajuda a atingir os objetivos específicos. A ciência é um árbitro legítimo das verdades relevantes, chamando a atenção, constantemente, para a extraordinária coerência de todas as forças em jogo, em todos os níveis da realidade, e abrindo debates, em que se pede que haja menos certezas e mais humildade.

Como em ciência não deve existir "moda", só quem não sabe o que é ciência se arrisca a opinar, sem olhar o outro lado da moeda. Pode, também, se interessar em explorar a capacidade de manipulação, em favor de interesses próprios, ou ao amparo do que cada um considera um bom motivo, esquecendo-se que motivos não são importantes por si próprios. Motivos são importantes, sim, quando aliados à fundamental necessidade do bem-estar de toda a sociedade, no presente e no futuro.

Mudar, em ciência, é importante, como importante é que os meios de informação o façam saber, não pela simples razão de ser "moda" mas para que nos aproximemos melhor da realidade. Claro exemplo é o nascer da biologia molecular. Em vez de pensarmos na célula em termos de energia e metabolismo, com a descoberta da estrutura do DNA mudamos nossos interesses, mais nos preocupando com a organização dos aminoácidos na composição das proteínas, o que se tornou ainda mais fácil com a descoberta do RNA. Um outro exemplo diz respeito ao processo da evolução, sobre o qual passou a ser "moda", recentemente, considerálo de pura ficção, levantando-lhe algumas dúvidas, dúvidas estas que têm origem na confusão que se faz entre a evolução, em si, e os mecanismos que lhe deram origem, esquecendo, ao 
mesmo tempo, o que a própria biologia molecular e a genética de populações nos têm ensinado. Tentar caracterizá-la como ficção é pura perda de tempo, além de nos deixar a terrível suspeita de que, face ao que ainda não conhecemos, o processo mais cativante de informar é fazê-lo de modo mais acessível, intelectualmente, com enorme carga de imaginação, confusão, determinação e paixão. Desejável será que tais "predicados" não venham a manifestar-se a respeito do seqüenciamento genômico humano.

É bom não esquecer que os benefícios concretos advindos deste novo saber talvez só venham a concretizar-se quando já tiver passado mais de um século. Tempo em que só constante, árduo e profícuo trabalho vai-nos elucidar sobre a atividade codificadora das dezenas de milhares de genes humanos e do quase imenso número de suas combinações. Ao termo imenso deu o físico Walter Elasser o significado de algo que descreve um número maior do que $10^{110}$.

Realmente, compreender os processos da ciência e suas idéias é tarefa árdua, razão pela qual surge sempre maior interesse pela tal apresentação da informação mais simplificada e atraente, com vistas a melhorar nossa vasta ignorância. Ou, quem sabe, talvez isso tenha sucedido pela imperiosa necessidade de cicatrizar alguma humilhante ferida na auto-estima intelectual.

José Alberto Neves Candeias Editor Associado 